\title{
Population status of the native Cottus gobio after removal of the alien Salmo trutta: a case-study in two Mediterranean streams (Italy)
}

\author{
Massimo Lorenzoni ${ }^{1}$, Antonella Carosi ${ }^{1, *}$, Massimo Giovannotti ${ }^{2}$, Gianandrea La Porta ${ }^{1}$, Andrea \\ Splendiani $^{2}$ and Vincenzo Caputo Barucchi ${ }^{2}$ \\ ${ }^{1}$ Dept. of Chemistry, Biology and Biotechnologies, University of Perugia, via Elce di Sotto, 06100 Perugia, Italy \\ ${ }^{2}$ Dipartimento di Scienze della Vita e dell'Ambiente, Università Politecnica delle Marche, via delle Brecce Bianche, 60131 Ancona, Italy
}

\begin{abstract}
In the Mediterranean area, one of the major threats to freshwater fish fauna is represented by the introduction of alien species. The bullhead, Cottus gobio, is a species of great conservation interest threatened by the massive introduction of hatchery-reared brown trout, Salmo trutta, for angling purposes. The aims of this research were: i) to present a case-study of interspecific and intraspecific competition in dwelling fish from two Mediterranean streams (central Italy); ii) to evaluate the bullhead population status before and after the alien brown trout removal, and iii) to investigate the influence of the environmental parameters on the abundance of both species. For the bullhead populations the abundances and the youngof-the-year percentage significantly increased after the removal activities. The growth analysis showed that, after the trout removal, bullhead were distinguished by greater performance and larger sizes in all age classes in comparison to the pre-removal period, while the condition factor $(K n)$ showed no differences, suggesting that the effects of trout population control acted mainly through predator-prey dynamics. An inverse correlation between the abundance of bullhead and its body condition suggested that the beneficial effects due to the reduction of predation could be compensated by the intraspecific competition due to the increase of the bullhead population density.
\end{abstract}

Keywords: Bullhead / Adriatic basin / environmental features / population analysis / biodiversity conservation

Résumé - Statut de la population native de Cottus gobio après retrait de Salmo trutta introduite: étude de cas dans deux rivières méditerranéennes (Italie). Dans la zone méditerranéenne, l'introduction d'espèces exotiques représente l'une des principales menaces pour la faune piscicole d'eau douce. Le chabot commun, Cottus gobio, est une espèce d'un grand intérêt pour la conservation menacée par l'introduction massive de truite fario d'écloserie, Salmo trutta, à des fins de pêche à la ligne. Les objectifs de cette recherche étaient les suivants: i) présenter une étude de cas sur la concurrence interspécifique et intraspécifique chez des poissons vivant dans deux cours d'eau méditerranéens (Italie centrale); ii) évaluer l'état de la population de chabot commun avant et après l'enlèvement de la truite fario introduite ; et iii) étudier l'influence des paramètres environnementaux sur l'abondance des deux espèces. L'abondance et le pourcentage de jeunes de l'année dans les populations de chabot commun ont augmenté de façon significative après les activités d'enlèvement. L'analyse de la croissance a montré qu'après l'enlèvement de la truite, le chabot commun se distinguait par une meilleure performance et des tailles plus grandes dans toutes les classes d'âge comparativement à la période précédant l'enlèvement, tandis que le facteur de condition $(K n)$ ne montrait aucune différence, ce qui suggère que les effets du contrôle de la population de truites étaient principalement dus à la dynamique prédateur-proie. Une corrélation inverse entre l'abondance du chabot commun et son état corporel suggère que les effets bénéfiques dus à la réduction de la prédation pourraient être compensés par la concurrence intraspécifique due à l'augmentation de la densité de population du chabot commun.

Mots clés : Chabot commun / bassin de l'Adriatique / caractéristiques environnementales / analyse de population / conservation de la biodiversité

\footnotetext{
*Corresponding author: acarosi@libero.it
} 


\section{Introduction}

The Mediterranean basin represents a hotspot for freshwater fish biodiversity (Smith and Darwall, 2006; Ribeiro and Leunda, 2012). The introduction of alien species represents one of the major threats to freshwater fish fauna in this area (Hermoso and Clavero, 2011). In fact, the introduction of invasive fish species may determine the alteration of aquatic ecosystem functionality (Marr et al., 2013) and affect the evolutionary processes of native species (Mooney and Cleland, 2001). Invaders can exert strong negative influence on native species through competitive interactions for food and habitat, niche displacement, predation and introgressive hybridization, leading to decreased population density and local extinction phenomena (Mooney and Cleland, 2001).

The bullhead (Cottus gobio Linnaeus, 1758) is a bottomdwelling freshwater fish species of great conservation interest, listed in Annex II of EU Habitats Directive as "of community interest whose consideration requires the designation of special areas of conservation". The core habitats of the species in Annex II should be managed in accordance with the ecological needs of the species themselves, but often this rule is disregarded. Although the species is widely distributed in Europe (Freyhof et al., 2005), it is threatened in many parts of its range by habitat alterations (Knaepkens et al., 2004), water pollution, water abstractions and predation by non-native species, such as brown trout (Salmo trutta Linnaeus, 1758), massively restocked for angling purposes (Zerunian, 2002). These threats have led to local extinction phenomena and the distribution range of this species is currently fragmented with many isolated populations (Legalle et al., 2005; Van Liefferinge et al., 2005).

The distribution range of $C$. gobio has undergone contraction in central Italy (Gandolfi et al., 1991). In the Tiber river basin the presence of the bullhead is currently restricted to three watercourses (Lorenzoni et al., 2010). Also in the Adriatic watersheds the distribution pattern of this species has become narrower in recent years (Franchi et al., 2012). Adriatic bullhead populations are of special conservational interest since they are located at the Southern limit of the European distribution range of the species. In particular, the Chienti river basin, in the South of the Marche region, represents the southern limit for this species (Lorenzoni and Esposito, 2011). In these areas, bullhead preferentially colonizes the upper stream reaches of the rivers, where the concentration of dissolved oxygen and flow velocity are high, the water quality is good (Jermacz et al., 2015) and the substrate is suitable for reproduction (Tomlinson and Perrow, 2003). These river stretches represent the ideal environments to highlight the negative effect of alien species invasion on the population status of the native bullhead. The life-history traits of the species, such as short generation time, early sexual maturity (2 years old) and short life expectancy (4 years) (Gandolfi et al., 1991), allow evaluating the effects of management actions on population dynamics in relatively short periods of time. Moreover, the ecological features of the bullhead, as poor vagility and the requirement of good environmental quality, along with the fact that it is not a target for sport fishing, make the species particularly suitable for evaluating the conservation status of freshwater ecosystems (Utzinger et al., 1998; Charles et al., 2008).
In central Italy, bullhead is often syntopic with brown trout (Lorenzoni et al., 2006; Franchi et al., 2012; Carosi et al., 2015), as also reported for many European countries, including England (Mann, 1971; Elliott, 2006), Belgium (Van Liefferinge et al., 2005) and Norway (Holmen et al., 2003). The adverse impacts of the introduction of brown trout on native species are widely documented in the literature (Crowl et al., 1992; Townsend, 1996; Penczak, 1999). The massive introduction of hatchery-reared brown trout for sport fishing purposes may cause the decline of native populations through predation of juveniles and interspecific competition phenomena (Simon and Townsend, 2003). Generally, these negative impacts are positively correlated with the abundance of the alien species (Didham et al., 2007). A previous study carried out in northern Italy (Bacchiglione river basin) showed that the negative effects on the distribution and abundances of bullhead populations were clearer in watercourses affected by massive restocking with hatchery-reared trout (Marconato, 1986). Both species are reported to have similar ecological preferences and similar feeding habits (Holmen et al., 2003; Elliott, 2006; Louhi et al., 2014). However, we cannot exclude diversifications in their diet or habitat preferences. A previous research conducted in some Adriatic basins (Franchi et al., 2012) showed the tendency of bullhead and brown trout to occupy different microhabitats within the same river stretch. In this context, it is important to investigate if the presence of the invasive hatchery-reared brown trout has had a negative impact on bullhead populations and to analyze the mechanisms that regulate the interactions between these two syntopic species.

Based on the hypothesis that the bullhead populations are subject to the negative effects of predation and/or interspecific competition caused by the presence of brown trout, the aims of the present research were: i) to present a case-study of interspecific and intraspecific competition in dwelling fish from two Mediterranean streams (central Italy); ii) to compare the population status of bullhead (Cottus gobio L.) before and after removal of the alien brown trout; iii) to investigate the relationships between the environmental parameters and the abundances of both species. The removal activities were carried out as concrete conservation action of the project LIFE12 NAT/IT/0000940 for the recovery of the native trout Salmo cettii Rafinesque, 1810 in the central Apennines (Italy); the suitable sites for the removal actions were selected on basis of genetic characterization that revealed the presence of trout populations composed almost exclusively of alien individuals. The river stretches targeted by removal activities are being subjected to the reintroduction of the native trout.

\section{Material and methods}

\subsection{Study area}

The study area encompasses two Adriatic watersheds, Cesano and Esino river basins (Fig. 1). The total watershed areas are respectively equal to $413 \mathrm{~km}^{2}$ and $1203 \mathrm{~km}^{2}$. The area is mainly characterized by a mountain calcareous system.

The river stretches identified for the trout removal activities were located in the upper stream reaches, at a short distance from the springs, in the Gorga creek (total stretch 


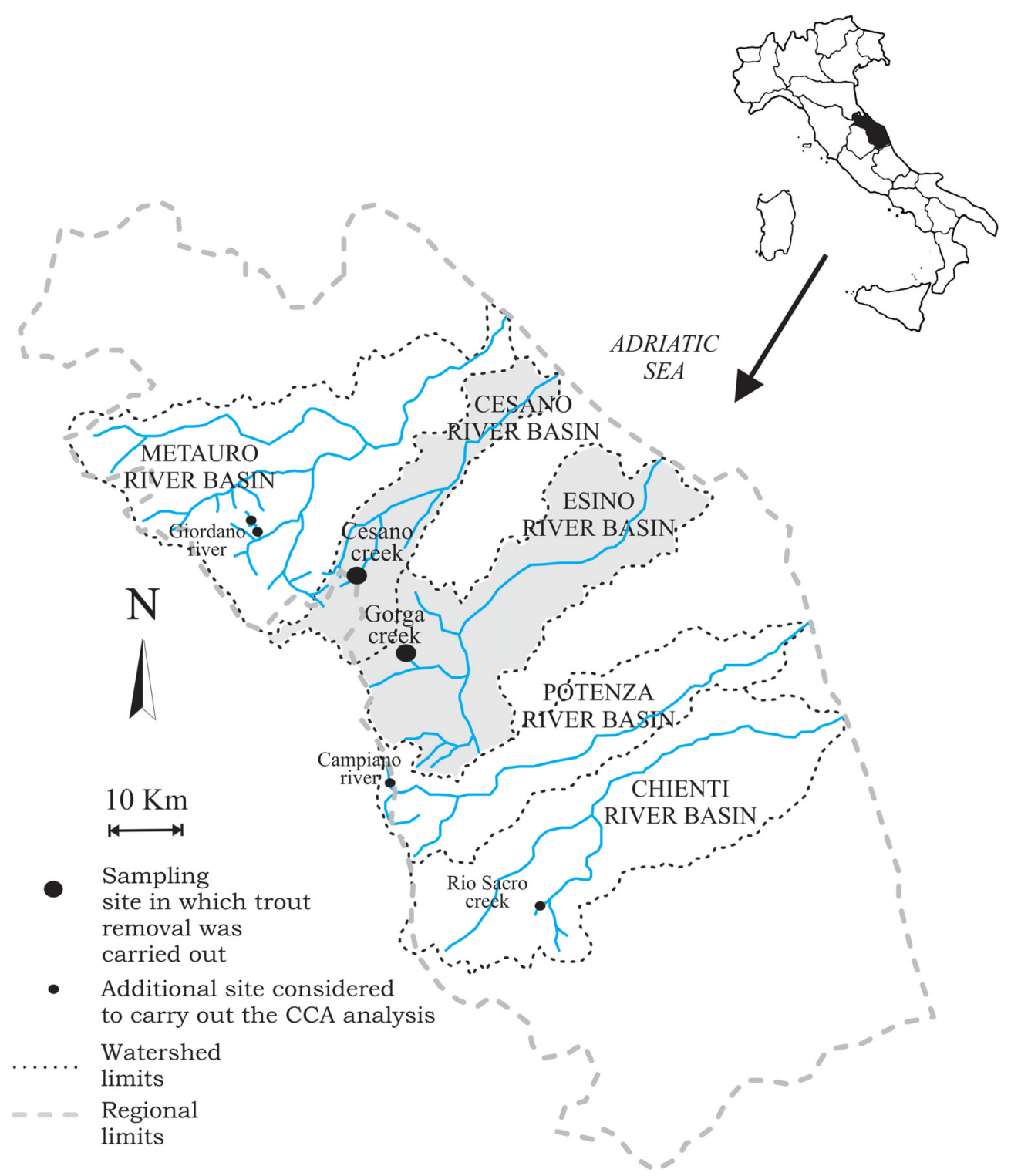

Fig. 1. Location of the study area in central Italy. The main map includes watershed areas, hydrographic network within each basin, location of the sampling sites selected for the trout removal and location of the additional sites considered to carry out the CCA.

length $2.4 \mathrm{~km})$ and in the Cesano creek $(4.82 \mathrm{~km})$ (Fig. 1). Watershed area, distance from the source, average slope and altitude were derived from digital maps (GIS; Tab. 1). The two watercourses are of modest dimensions, in terms of average width and depth, and have similar environmental characteristics such as hydrogeology and flow rates. Both streams have torrential features, with marked flow rate oscillations and a high susceptibility to periods of drought in summer, made worse by the intensive exploitation for potable use (Lorenzoni and Esposito, 2011). The two selected watercourses represent a suitable model to study the prey-predator interaction between stream-dwelling fish due to: i) isolation from the rest of the watercourse by the presence of either natural or human-made weirs that are insurmountable from fish fauna; ii) brown trout and bullhead are the only fish species inhabiting these river stretches.

\subsection{Data collection}

Fish data were collected from March 2014 to April 2017 in two sampling sites (Fig. 1). A total of 11 samplings of fish fauna were carried out at each sampling site by two-pass electrofishing using the removal method (Moran, 1951; Zippin, 1956). Fish were captured during low flow periods using a continued or pulsed electric current with power varying between 600 and $4000 \mathrm{~W}$. The sampling was carried out in downstream to upstream direction for two consecutive times, applying the same fishing effort (Seber and Le Cren, 1967). The stretch length considered for data collection was $82.7 \mathrm{~m}$ for the Gorga creek and $75.1 \mathrm{~m}$ for the Cesano creek. The first two samplings (preliminary surveys) were carried out before the removal of brown trout started (from March 2014 to February 2015 for the Cesano creek; from March 2014 to May 
Table 1. Phisico-chemical and morpho-hydrological characterization for the two sampling sites located in Gorga and Cesano creeks, respectively.

\begin{tabular}{|c|c|c|c|c|}
\hline \multirow[b]{2}{*}{ Environmental parameters } & \multicolumn{2}{|c|}{ Gorga creek } & \multicolumn{2}{|c|}{ Cesano creek } \\
\hline & Mean $( \pm \mathrm{SD})$ & Range & Mean $( \pm \mathrm{SD})$ & Range \\
\hline Altitude (m a.s.1.) & 538 & - & 472 & - \\
\hline Slope $(\%)$ & 6.38 & - & 14.54 & - \\
\hline Distance from the source $(\mathrm{km})$ & 2.14 & - & 5.37 & - \\
\hline Watershed area $\left(\mathrm{km}^{2}\right)$ & 6.86 & - & 12.06 & - \\
\hline $\mathrm{BOD}_{5}\left(\mathrm{mg} \cdot \mathrm{L}^{-1}\right)$ & $1.45 \pm 0.49$ & $1.10-1.80$ & $1.70 \pm 0.71$ & $1.20-2.70$ \\
\hline Canopy cover $(\%)$ & $0.00 \pm 0.00$ & $0.00-0.00$ & $12.50 \pm 5.00$ & $10.00-20.00$ \\
\hline $\mathrm{Cl}\left(\mathrm{mg} \cdot \mathrm{L}^{-1}\right)$ & $8.00 \pm 2.83$ & $6.00-10.00$ & $8.50 \pm 3.70$ & $6.00-14.00$ \\
\hline $\operatorname{COD}\left(\mathrm{mg} \cdot \mathrm{L}^{-1}\right)$ & $0.83 \pm 0.00$ & $0.83-0.83$ & $0.83 \pm 0.00$ & $0.83-0.83$ \\
\hline Conductivity $\left(\mu \mathrm{S} \cdot \mathrm{cm}^{-1}\right)$ & $441.50 \pm 129.40$ & $350.00-533.00$ & $467.50 \pm 119.88$ & $340.00-615.00$ \\
\hline Depth $(\mathrm{cm})$ & $15.50 \pm 6.17$ & $7.92-27.78$ & $11.16 \pm 4.30$ & $6.01-17.87$ \\
\hline Dissolved oxygen $\left(\mathrm{mg} \cdot \mathrm{L}^{-1}\right)$ & $12.73 \pm 1.39$ & $11.75-13.71$ & $10.62 \pm 1.70$ & $9.10-12.47$ \\
\hline Flow rate $\left(\mathrm{m}^{3} \cdot \mathrm{s}^{-1}\right)$ & $0.300 \pm 0.33$ & $0.07-0.53$ & $0.04 \pm 0.05$ & $0.02-0.11$ \\
\hline $\mathrm{NNH}_{3}\left(\mathrm{mg} \cdot \mathrm{L}^{-1}\right)$ & $1.01 \pm 0.01$ & $1.01-1.02$ & $1.05 \pm 0.07$ & $1.01-1.15$ \\
\hline pH (units) & $9.11 \pm 0.01$ & $9.10-9.12$ & $9.27 \pm 0.22$ & $9.06-9.50$ \\
\hline $\mathrm{PPO}_{4}\left(\mathrm{mg} \cdot \mathrm{L}^{-1}\right)$ & $1.01 \pm 0.00$ & $1.01-1.01$ & $1.06 \pm 0.03$ & $1.01-1.08$ \\
\hline Shaded surface (\%) & $22.50 \pm 10.61$ & $15.00-30.00$ & $67.50 \pm 8.66$ & $60.00-75.00$ \\
\hline $\mathrm{SO}_{4}\left(\mathrm{mg} \cdot \mathrm{L}^{-1}\right)$ & $13.50 \pm 0.71$ & $13.00-14.00$ & $7.75 \pm 5.25$ & $3.00-15.00$ \\
\hline Water temperature $\left({ }^{\circ} \mathrm{C}\right)$ & $11.95 \pm 0.64$ & $11.50-12.40$ & $13.22 \pm 1.67$ & $11.60-15.20$ \\
\hline Width $(\mathrm{m})$ & $2.16 \pm 0.48$ & $1.60-2.60$ & $2.60 \pm 0.59$ & $1.60-3.20$ \\
\hline
\end{tabular}

2015 for the Gorga creek), whereas the other nine samplings were carried out during the removal practices, which started in February 2015 and May 2015 for the Cesano and Gorga creeks, respectively. For all caught fish, the species was identified and individuals counted in order to determine the species abundance, in terms of density (ind $\cdot \mathrm{m}^{-2}$ ) and standing crop $\left(\mathrm{g} \cdot \mathrm{m}^{-2}\right)$. For all specimens, total length $(T L)$ was measured to the nearest $0.1 \mathrm{~cm}$, and body weight to the nearest $0.1 \mathrm{~g}$ (Anderson and Neumann, 1996). For each trout caught, a sample of scales was collected for age determination according to the scalimetric method (Bagenal, 1978). During the first two samplings, all the fish caught were released into their natural environment at the end of the field works; by contrast during the removal practices only the bullheads were released in the sampling site, while brown trout were removed and transferred to private sport fishing ponds. Age of bullheads was determined using the analysis of the length-frequency distribution (Bagenal, 1978; Cowx and Harvey, 2003).

Environmental data were collected during the preliminary surveys at the same time as fish data collection. Nineteen environmental parameters were used to characterize the sampling locations (Tab. 1). The flow rate was measured at the cross-sectional area of each sampling reach, using an OTT MF-pro electromagnetic current meter (ISO 748:2007 Hydrometry - Measurement of liquid flow in open channels using current-meters or floats). Field measurements of specific conductivity, $\mathrm{pH}$, water temperature and dissolved oxygen were carried out with electronic meters manufactured by YSI, Hanna Instruments and WTW GmbH. Other chemical parameters of the water (dissolved oxygen, $\mathrm{NNO}_{3}, \mathrm{NNH}_{3}, \mathrm{SO}_{4}, \mathrm{PPO}_{4}, \mathrm{Cl}, \mathrm{COD}$ ) were determined according to APAT et al. (2003) specifications. Canopy cover and shaded areas were estimated by visual observation as the percentage of the total surface.
In order to have a larger dataset to investigate the influence of the environmental parameters on the abundance of bullhead and brown trout by multivariate analysis, fish and environmental data were collected in other four sites besides Gorga and Cesano creek: two sites were located in the Giordano river (Metauro river basin), one site was located in the Campiano river (Potenza river basin) and one site was located in the Rio Sacro creek (Chienti river basin) (Fig. 1). These six sites were sampled two times (in spring and autumn 2014) during the preliminary surveys before the trout population control, and the presence of the bullhead and the brown trout was detected in all the sampling sites.

\subsection{Growth and estimation of body condition}

The total Length-Weight Relationship (LWR) was estimated for the total sample and separately for Gorga and Cesano creeks. The LWR was estimated by the least-squares method (Ricker, 1975) based on the logarithmic equation: $\log _{10} W$ $(\mathrm{g})=a+b \log _{10} T L(\mathrm{~cm})$, where $a$ is the intercept on the Y-axis and $b$ is the regression coefficient. The standard error was calculated for the slope (b) of LWR. Isometric growth was tested through $t$-test, using the equation:

$$
t_{\mathrm{s}}=b-3 / S_{\mathrm{b}} \text {, }
$$

where $S_{\mathrm{b}}$ is the standard error of the slope (b), for $\alpha=0.05$ (Sokal and Rohlf, 1987). The theoretical growth was estimated separately for the two bullhead populations, using the von Bertalanffy growth curve model (von Bertalanffy, 1938): $T L_{\mathrm{t}}=L_{\infty}\left(1-e^{-k(t-t 0)}\right)$ where $T L_{\mathrm{t}}$ is the total length of the fish at time $t, L_{\infty}$ the theoretical maximum length $(\mathrm{cm}), k$ the rate of approach to $L_{\infty}$, and $t_{0}$ the theoretical age at which $T L_{\mathrm{t}}=0$. Furthermore, the index of growth performance $\left(\Phi^{\prime}\right)$ was 
calculated by the equation of Pauly and Munro (1984): $\Phi^{\prime}=\log _{10} k+2 \log _{10} L_{\infty}$ where $k$ and $L_{\infty}$ are the growth parameters of the Von Bertalanffy model.

As a contribution to the assessment of the impact of alien brown trout on the bullhead, the relative condition factor $(K n)$ of bullhead was assessed and the mean values for each age class and for the two periods (before and after removal activities) were compared. This approach is based on the assumption that high $K n$ values characterize fish in good condition and good health, while low $K n$ values are typical of fish in poor body condition (Blackwell et al., 2000). The relative condition factor (Le Cren, 1951) was calculated using the equation: $K n=100 \mathrm{~W} /\left(a T L^{b}\right)$, where $a$ and $b$ are the coefficients of the LWR equation estimated from the total sample. Only fish of a total length higher than $4.0 \mathrm{~cm}$ were used to perform the analysis. In fact, for fish $<4.0 \mathrm{~cm}$ the error associated with the accuracy of the weight measure is too high.

\subsection{Statistical analysis}

Canonical Correspondence Analysis (CCA), a direct gradient analysis method that allows examining the relationships among multivariate ecological data matrices (ter Braak, 1986) was used in order to extract the environmental variables that drive the fish demographic parameters, in particular the abundance, measured in terms of density (ind $\cdot \mathrm{m}^{-2}$ ) and standing crop $\left(\mathrm{g} \cdot \mathrm{m}^{-2}\right)$, and the $K n$ of the bullhead. The environmental variables to be included in the analysis were previously selected by a Principal Component Analysis. The six environmental variables more strongly associated with each of the first six components have been chosen and the final environmental matrix included 6 environmental parameters and twelve observations (6 sampling sites $\times 2$ sampling events). The demographic matrix included $K n$ (only for the bullhead), density and standing crop for both species (bullhead and brown trout) and twelve observations ( 6 sampling sites $\times 2$ sampling events). All variables $(N)$ used in the analysis were transformed $\left[\log _{10}(N+1)\right]$ to normalize their distributions (Brown and Austen, 1996) and standardized to a mean of 0 and standard deviation of 1 . Statistical significance was tested with Monte Carlo permutation test (999 permutations) and a Generalized Linear Models (GLM) was used. To fit the relationship between the demographic parameters and the environmental variables resulted statistically related with the axes 1 of the CCA.

A two-way (stream $\times$ time) repeated-measures ANOVA was performed in order to test the significance of the changes occurred over time in the density and standing crop of alien brown trout and bullhead populations of Gorga and Cesano creeks. Data were tested for sphericity using the Mauchly test and the Greenhouse-Geisser and Huynh-Feldt adjustements were used. For the bullhead, the significance of the condition factor differences for specific age classes between pre- and post-removal periods was evaluated by a three-way ANOVA (streams $\times$ age class $\times$ period). The same analysis was carried out to compare the mean total length values between streams, age class and periods. Spearman Rank Order Correlations analysis was carried out to evaluate the relationships between the condition factor and the demographic parameter of the bullhead populations.

\section{Results}

\subsection{Environmental characterization}

Water temperature ranged from $11.5^{\circ} \mathrm{C}$ to $15.2^{\circ} \mathrm{C}$ (Tab. 1). Dissolved oxygen ranged from 9.10 to $13.71 \mathrm{mg} \cdot \mathrm{L}^{-1}$. Conductivity varied from $340.00 \mu \mathrm{S} \cdot \mathrm{cm}^{-1}$ to $615.00 \mu \mathrm{S} \cdot \mathrm{cm}^{-1}$. Both sites were characterized by low concentration of dissolved salts. The flow rate ranged between 0.02 and $0.53 \mathrm{~m}^{3} \cdot \mathrm{s}^{-1}$. The sampling site located in Gorga creek presented lower percentages of canopy cover $(0 \%)$ and average shaded surface (mean $\pm \mathrm{SD}=22.50 \pm 10.61)$ than the Cesano creek.

\subsection{Demographic characteristics}

Brown trout and bullhead were the only fish species inhabiting the two sites investigated. Before the start of removal activities the brown trout was dominant in terms of biomass but not in density.

A total of 2071 bullhead specimens were collected. The size of the sampled fish ranged from 1.0 to $11.8 \mathrm{~cm}$ (mean $\pm \mathrm{SD}=6.50 \pm 1.89$ ) and weight from 0.4 to $23.0 \mathrm{~g}$ (mean $\pm \mathrm{SD}=4.80 \pm 3.60)$. Five age classes $\left(0^{+}\right.$to $\left.4^{+}\right)$were identified (Appendix 1). A total of 925 trout individuals were collected; 119 specimens were sampled during the preliminary surveys, while 806 trout were removed during the eradication activities. The total length of the collected trout ranged from 3.0 to $38.5 \mathrm{~cm}$ and eight age classes $\left(0^{+}\right.$to $\left.7^{+}\right)$were identified.

From the comparison of the mean abundances values, broken down for each watercourse and for each sampling, an overall increase in density over time in both bullhead populations emerged, more markedly in the last three samplings (Fig. 2). For the standing crop, an increase of the mean values over time was detected for the Cesano creek only, while for the Gorga creek a more fluctuating trend was observed. The differences between samplings (density: $F=27.64, d f=10, p=0.001$; standing crop: $F=8.81, d f=10$, $p=0.008$ ) resulted statistically significant at the two-way repeated-measures ANOVA. The differences of the bullhead abundances between streams and the interactions among samplings and streams resulted not statistically significant $(p>0.05)$.

The results of the age-based demographic trend of bullhead in both Cesano and Gorga creeks (Fig. 3) showed that the increase in abundance values in the post-trout removal periods was due to the prevalence of the YOY $\left(0^{+}\right)$specimens, representing more than $40 \%$ of the total population, while there was a considerable decrease in the age class $2^{+}$individuals.

The removal practices resulted in a drastic decrease in the abundance of brown trout populations. For the Gorga creek, the last sampling highlighted a population density and a biomass equal to $20.51 \%$ and $1.67 \%$, respectively, of values recorded in the pre-removal period; for the Cesano creek the population density and the biomass in the last sampling resulted equal to $0.00 \%$. The differences between the abundance values calculated for each sampling were statistically significant for the standing crop $(F=4.06, d f=10$, $p=0.015)$ but not for the density $(F=1.74, d f=10, p=0.188)$ at the two-way repeated-measures ANOVA, and the differences between streams were not statistically significant. By 


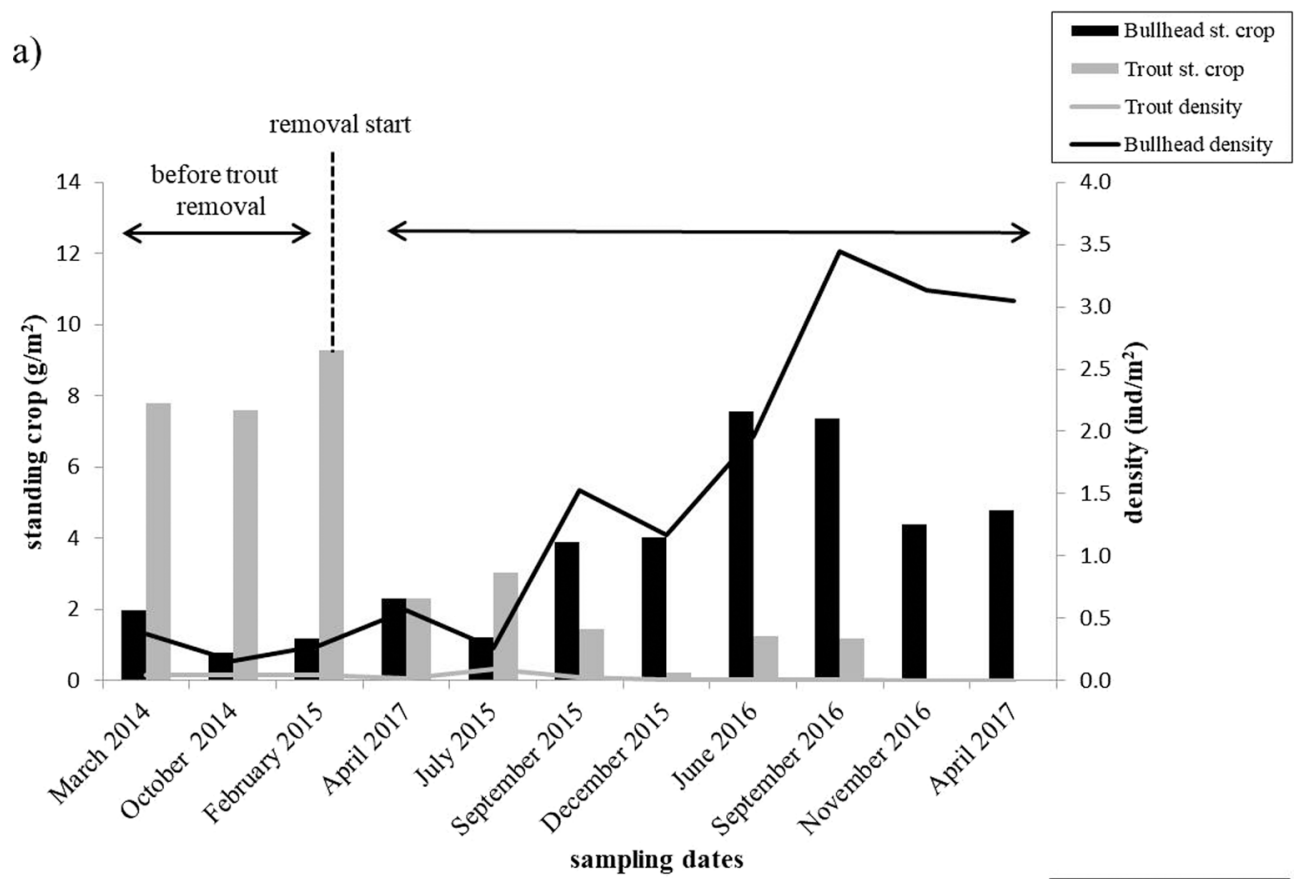

b)

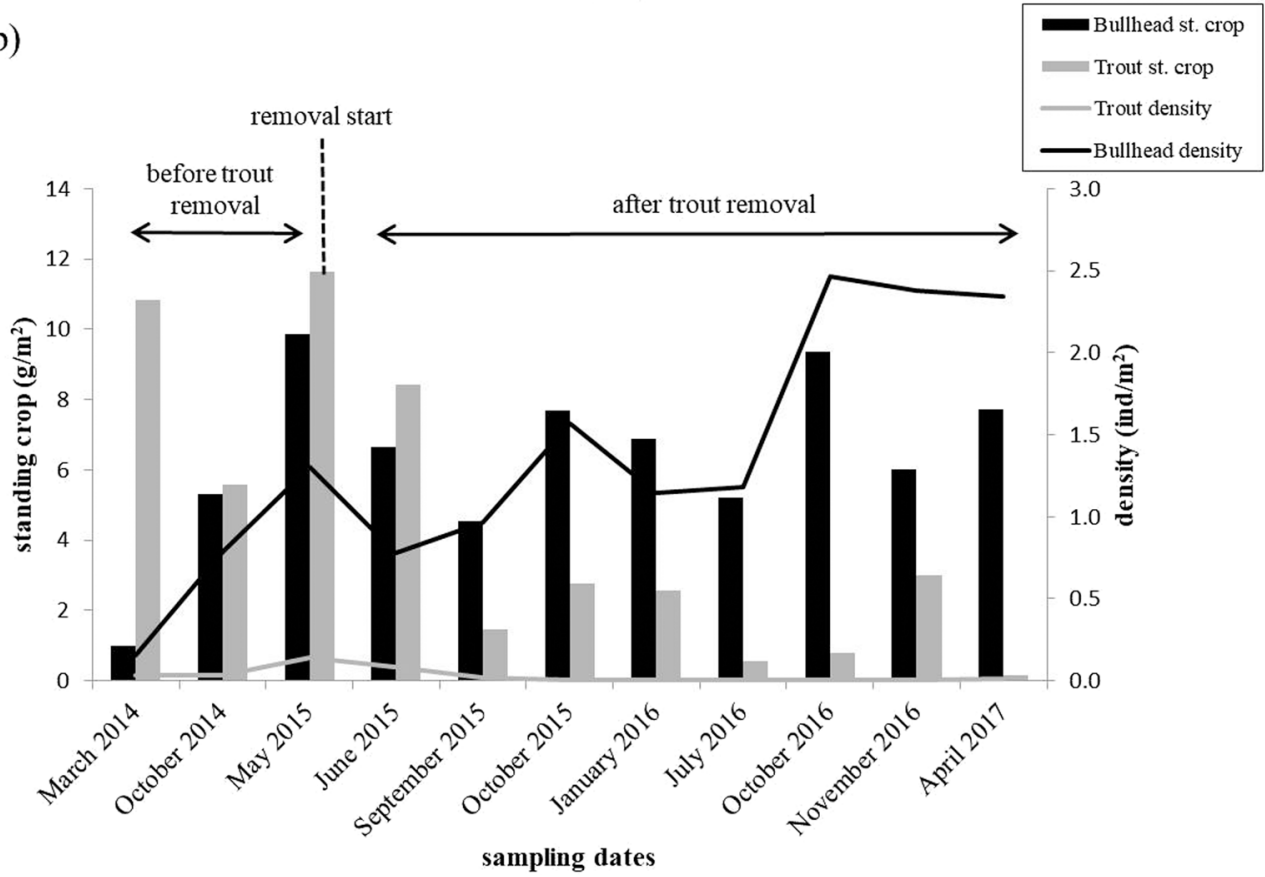

Fig. 2. Mean density (lines) and standing crop values (histograms) for bullhead and brown trout broken down by the 11 samplings carried out between March 2014 and April 2017: a) Cesano creek; b) Gorga creek.

contrast, the size-structure analyses highlighted the drastic reduction of specimens larger than $10 \mathrm{~cm}$ (age class $>1$ years) after removal activities for both creeks (Fig. 4).

\subsection{Growth}

The LWR for the total sample was $W=0.025 T L^{2.689 \pm 0.02}$ $\left(R^{2}=0.91\right)$. The b (slope) value was significantly lower than three $(t=14.81 ; p=0.001)$, indicating negative allometric growth (Ricker, 1975). The LWR equations estimated separately for the Gorga and Cesano creeks were
$W=0.030 T L^{2.635 \pm 0.03} \quad\left(R^{2}=0.92 ; t=12.33 ; p<0.05\right) \quad$ and $W=0.023 T L^{2.719 \pm 0.03}\left(R^{2}=0.90 ; t=9.97 ; p<0.05\right)$, respectively, indicating that $\mathrm{b}$ significantly differ from isometric growth.

Theoretical growth parameters and $\Phi^{\prime}$ values were calculated separately for the populations of Gorga and Cesano creeks (Fig. 5). The results of the comparison of the theoretical growth curves calculated for both populations before and after removal activities showed that, in absence of trout, the bullhead was distinguished by greater performance and larger sizes in all age classes in comparison to the pre-removal 
M. Lorenzoni et al.: Knowl. Manag. Aquat. Ecosyst. 2018, 419, 22
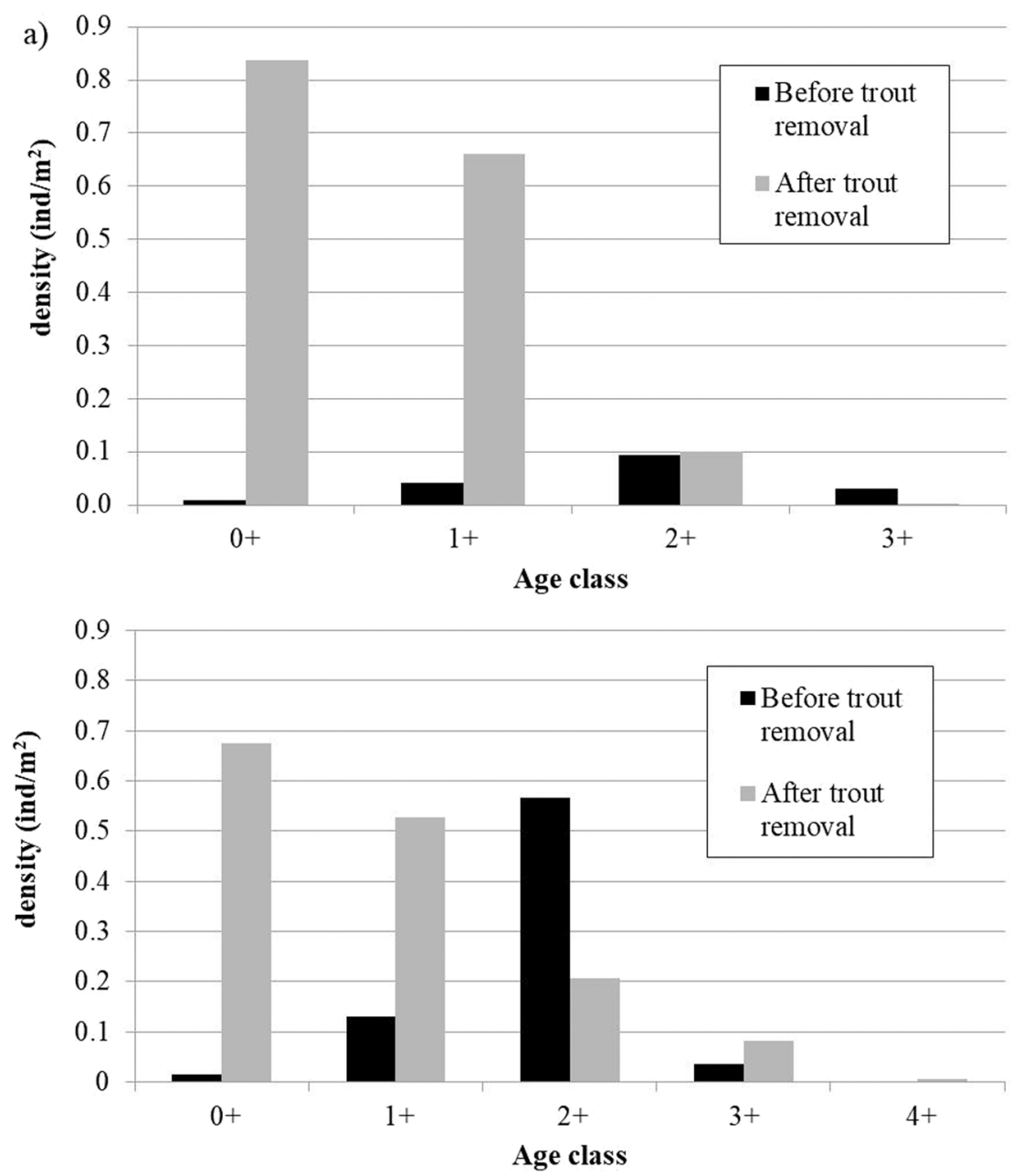

Fig. 3. Age-based demographic trend for bullhead broken down before (black histograms) and after (grey histograms) trout removal performed separately for each sampling site: a) Cesano creek; b) Gorga creek.

period. For both populations the differences between the mean values of total length between periods at different age classes (period $\times$ age class: $F=5.94, p=0.001$ ) were statistically highly significant according to the three-way analysis of variance.

\subsection{Condition factor}

The differences among the age classes and between the two watercourses on the bullhead $K n$ mean values resulted statistically significant at the three-way factorial analysis of variance (age class: $F=11.62, p=0.001$; watercourse: $F=5.65, p=0.018$ ), while the differences in the comparison between pre- and post-removal periods and the crossing effects between the categorical variables were not statistically significant. Only the differences between periods of the $2^{+}$ age class mean values for the Cesano creek resulted statistically significant at the Fisher's LSD Post Hoc test $(p=0.001)$. Except for the Gorga creek before trout removal, in the other cases the results showed a progressive increase in the body condition with age (Fig. 6). The results of the Spearman Rank Order Correlation analysis showed an inverse correlation between $K n$ and bullhead density $\left(r_{\mathrm{s}}=-0.353 ; p<0.05\right)$.

\subsection{Relationship among environmental, demographic parameters and $K n$}

In the Canonical Correspondence Analysis the Monte Carlo test showed statistically highly significant results for all canonical axes $(F=4.10 ; p=0.002$; total inertia $=0.15)$. The first axis of the CCA explained $63.30 \%$ of the overall variability, while the second axis is less informative and explained $30.30 \%$ of the total variability (Fig. 7). A direct correlation between the distance from the source and the first axis was observed $(p=0.023)$ (Tab. 2). Regarding the demographic parameters, a positive correlation of the bullhead density $(p=0.001)$ and standing crop $(p=0.001)$ with the axis 1 was observed; the brown trout density $(p=0.001)$ and standing crop values $(p=0.048)$ were directly correlated with axis 2 .

The results of the GLM analysis showed a significant negative slope between bullhead density and distance from the source; the equation was: density $=-0.176$ distance from the source ${ }^{0.722}(F=7.8 ; p=0.016)$, while for the other demographic parameters and $K n$, the analysis did not reveal significant relationships with the distance from the source. 
a)
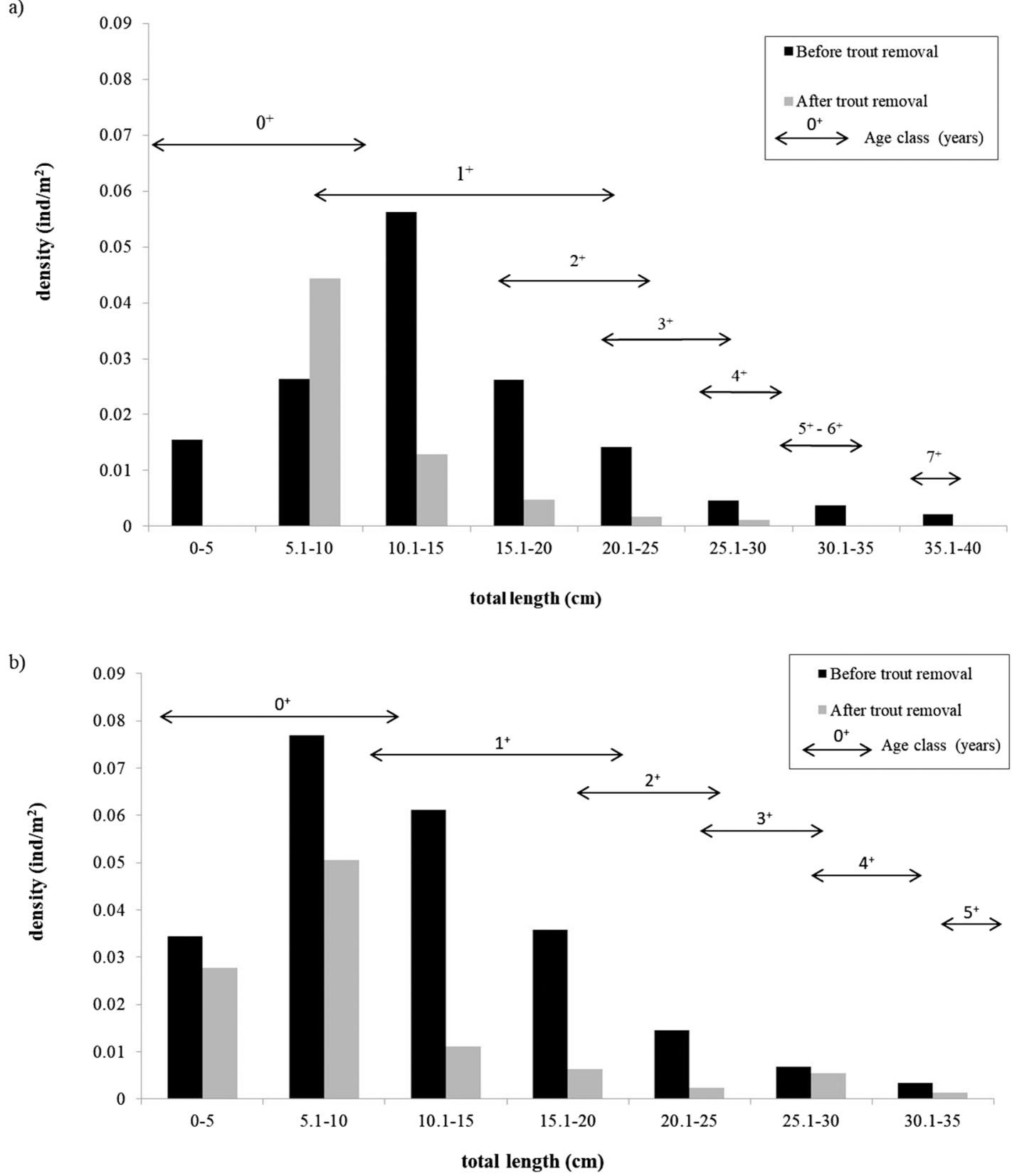

Fig. 4. Size structure in terms of density for total length class of the brown trout populations before (black histograms) and after (grey histograms) removal practices performed separately for each sampling site: a) Cesano creek; b) Gorga creek. The age classes identified by length class are also indicated.

\section{Discussion}

The environmental characterization confirmed that the bullhead colonizes stream reaches with good water quality, where the concentration of the dissolved oxygen is high and the water temperature is low (Tomlinson and Perrow, 2003). The distance from the source and the abundance of the bullhead were the most closely related parameters with axis 1 of the CCA, which represents the trophic gradient of the watercourse. GLM results confirmed that the distance from the source represents the major driver in the abundance of the bullhead, which seems to prefer upper stream reaches, located at a short distance from the source.

Otherwise than that it was detected for density, the demographic investigation revealed that before the start of removal activities, the biomass of alien brown trout was greater than that of the bullhead. The bullhead population densities observed after the trout removal exceeded the optimal values $\left(>0.6\right.$ ind $\left.\cdot \mathrm{m}^{-2}\right)$ expected for the species in mountain stream reaches, as recorded in the headwaters of Norfolk rivers (Gosselin et al., 2010), and reaching density values above $2.0 \mathrm{ind} \cdot \mathrm{m}^{-2}$ as reported by Tomlinson and Perrow (2003) for Yorkshire Dales rivers. 

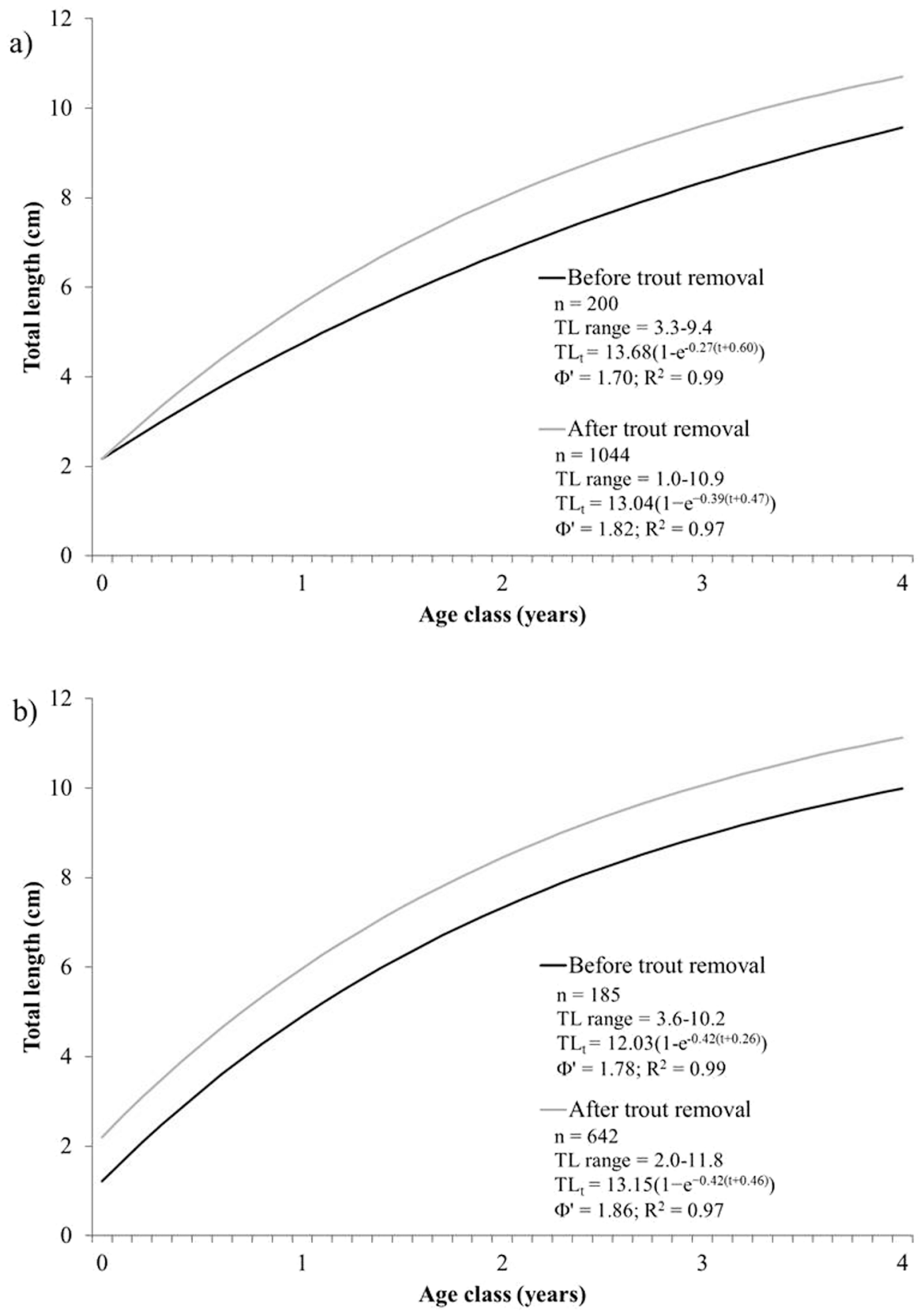

Fig. 5. Comparison of the theoretical growth curves for bullhead before (black line) and after (gray line) trout removal, calculated separately for each sampling site: a) Cesano creek; b) Gorga creek.

The growth analysis is particularly effective in describing the health of a fish population and it helps to evaluate the effects of different management actions (Pedicillo et al., 2010). The parameters of the theoretical growth curves calculated separately for the two bullhead populations showed that, after the trout removal actions, they were distinguished by greater performance and larger sizes in all age classes in comparison to the pre-removal period. The comparison with the theoretical growth parameters reported for two populations from the U.K. indicated that the bullhead populations from the Gorga and Cesano creeks showed higher values for $\Phi^{\prime}$ and maximum theoretical lengths (Tab. 3). Nevertheless, the change rate of body shape, calculated for the total sample, was significantly lower than three, indicating a negative allometric growth (Ricker, 1975). This slope value was different from the values previously recorded in central Italy (Tiber river basin), with bullhead populations showing $b$ values greater than three (Tab. 4). These deviations could be related to the differences in size structure and contribution of age classes among the compared bullhead populations. The estimated maximum age of $4^{+}$is consistent with data reported for other European populations, although a maximum age of $10^{+}$is indicated in the literature for this species (Mills and Mann, 1983). The maximum size observed in the present study $(T L=11.80 \mathrm{~cm})$ did not reach the maximum total length of $18.00 \mathrm{~cm}$ recorded for the species (Muus and Dahlström, 1968). 

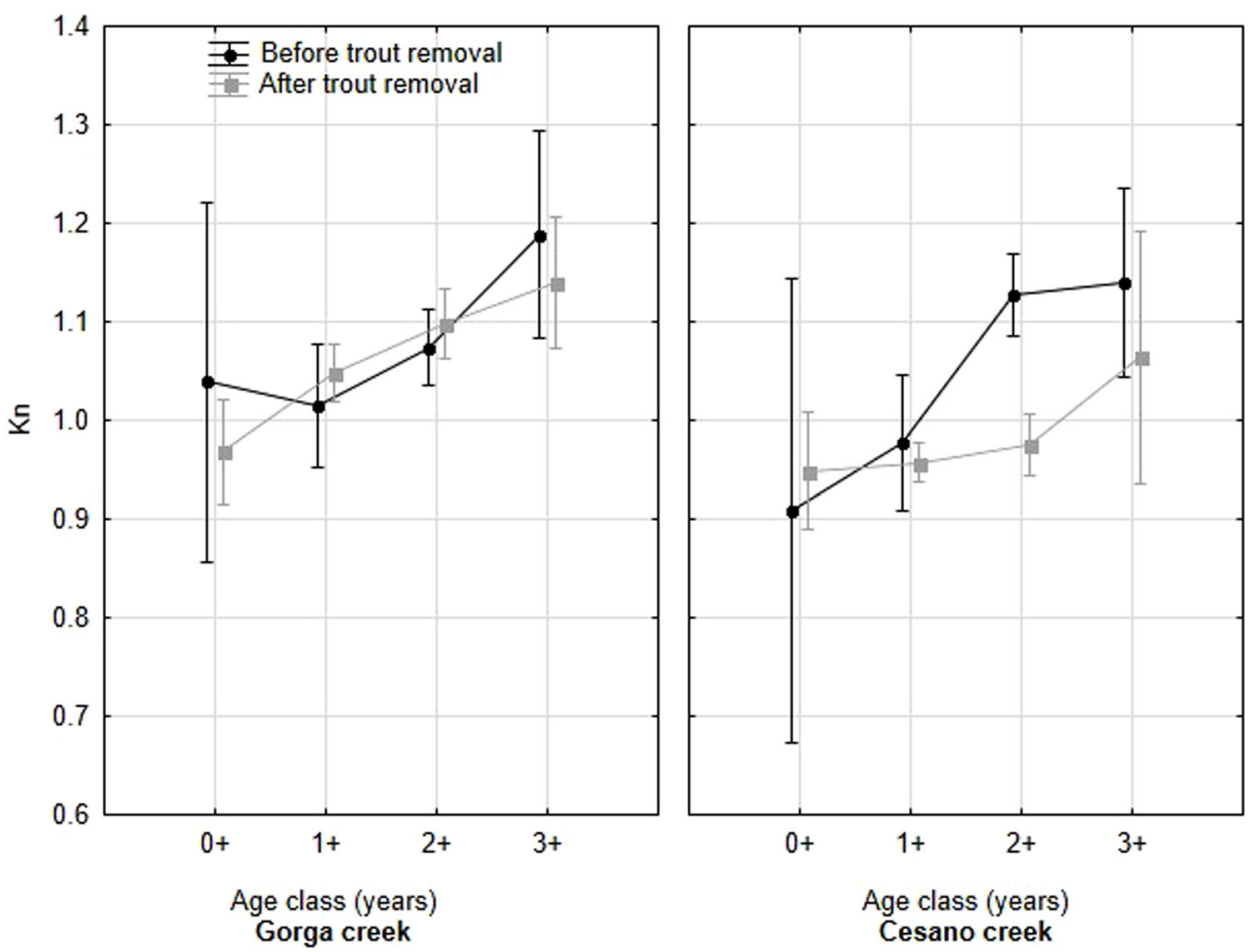

Fig. 6. Comparison of the condition factor mean values for bullhead, broken down by age class before (black circles) and after (gray squares) trout removal, performed for Gorga and Cesano creeks, separately. Upper and lower bars represent the 95\% confidence limits.

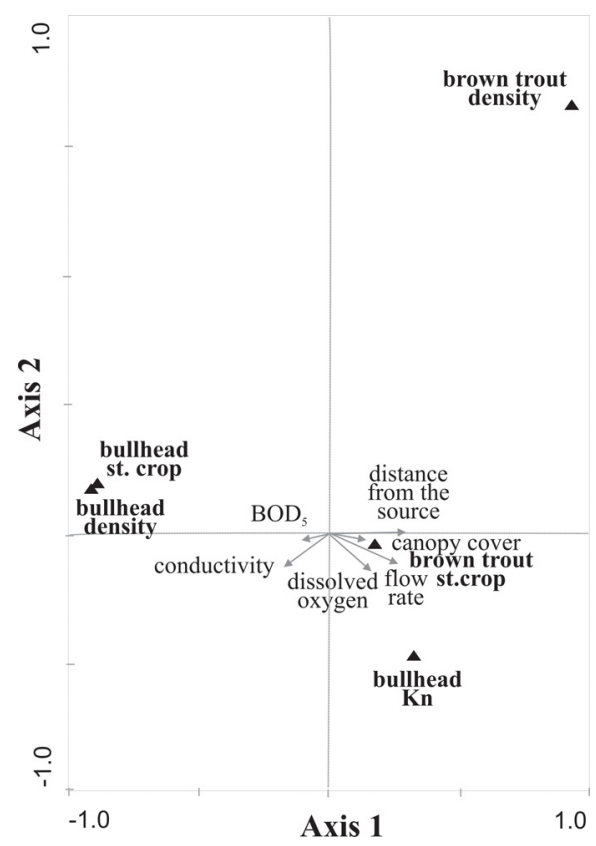

Fig. 7. Canonical Correspondence Analysis (CCA): biplot of the environmental matrix showing environmental variables (grey arrows) and of the fish matrix with densities and standing crop of the brown trout, and densities, standing crop, $K n$ of the bullhead (black triangles). The first two ordination axes explained $93.30 \%$ of the total variance. Eigenvalues of axis 1 and 2 were 0.082 and 0.027 , respectively. The length of each arrow is proportional to the rate of change and indicates the strength of the correlation with the axes.
Generally, the worsening of body condition of a native species, subsequent to non-native species invasion, can provide evidence for competition for food and habitat (Irons et al., 2007). Previous studies have shown the effectiveness of body condition indices, as well as relative weight and condition factor, as tools to verify the presence of competitive interaction phenomena between non-native and native fish species in the Tiber river basin (Giannetto et al., 2012; Carosi et al., 2016, 2017). However, in the present study the results of the bullhead condition factor showed statistically nonsignificant differences between the periods before and after trout removal, except the worsening of the body condition of specimens belonging to the $2^{+}$age class of the Cesano creek. This result suggests that probably interspecific competition phenomena do not occur between brown trout and bullhead in the study sites. According to Elliott (2006) and Holmen et al. (2003), in cases where bullhead and brown trout coexist, diversifications in their diet and habitat preferences occur, as showed also by previous studies carried out in the same area (Franchi et al., 2012). Strong competition between the two species has been demonstrated in conditions of poor food availability, while poor habitat availability seems to favor the species with lower population density (Elliott, 2006).

The present case-study showed that probably the presence of brown trout exerts a negative effect on bullhead populations mainly through a predator-prey interaction. This hypothesis is supported by: i) the changes in the size and age-structure of trout population between the two periods, with a drastic reduction of biggest specimens and therefore of potential predators; ii) the presence of abundant and well-structured bullhead populations in the post-removal periods, and in 
M. Lorenzoni et al.: Knowl. Manag. Aquat. Ecosyst. 2018, 419, 22

Table 2. CCA results. Canonical and correlation coefficients of environmental and biological variables with axis 1 and $2 . P<0.05$ is in bold.

\begin{tabular}{|c|c|c|c|c|c|c|}
\hline \multirow[b]{2}{*}{ Environmental and biological parameters } & \multicolumn{2}{|c|}{ Canonical coefficients } & \multicolumn{4}{|c|}{ Correlations with axis } \\
\hline & AX1 & AX2 & AX1 & $p$ & $\mathrm{AX} 2$ & $p$ \\
\hline $\mathrm{BOD}_{5}\left(\mathrm{mg} \cdot \mathrm{L}^{-1}\right)$ & -0.094 & -0.160 & -0.282 & 0.328 & -0.082 & 0.780 \\
\hline Canopy cover $(\%)$ & 0.263 & -0.308 & 0.274 & 0.344 & -0.042 & 0.886 \\
\hline Conductivity $\left(\mathrm{S} \cdot \mathrm{cm}^{-1}\right)$ & -0.443 & -0.517 & -0.343 & 0.230 & -0.295 & 0.305 \\
\hline Dissolved oxygen $\left(\mathrm{mg} \cdot \mathrm{L}^{-1}\right)$ & -0.064 & -0.650 & 0.409 & 0.147 & -0.413 & 0.142 \\
\hline Distance from the source $(\mathrm{km})$ & 0.059 & 0.222 & 0.601 & 0.023 & -0.143 & 0.625 \\
\hline Flow rate $\left(\mathrm{m} \cdot \mathrm{s}^{-1}\right)$ & 0.514 & -0.139 & 0.525 & 0.054 & -0.398 & 0.159 \\
\hline Brown trout density (ind $\cdot \mathrm{m}^{-2}$ ) & 0.951 & 1.648 & 0.261 & 0.368 & 0.838 & 0.001 \\
\hline Brown trout standing crop $\left(\mathrm{g} \cdot \mathrm{m}^{-2}\right)$ & 0.175 & -0.050 & -0.338 & 0.237 & 0.537 & 0.048 \\
\hline Bullhead density (ind $\cdot \mathrm{m}^{-2}$ ) & -0.919 & 0.168 & -0.769 & 0.001 & 0.324 & 0.259 \\
\hline Bullhead standing crop $\left(\mathrm{g} \cdot \mathrm{m}^{-2}\right)$ & -0.897 & 0.191 & -0.871 & 0.001 & 0.368 & 0.195 \\
\hline Bullhead $K n$ & 0.341 & -0.470 & -0.333 & 0.244 & 0.114 & 0.697 \\
\hline
\end{tabular}

Table 3. Parameters of the theoretical growth for bullhead populations from different countries.

\begin{tabular}{llllrr}
\hline Location & Country & References & Sex & $L_{\infty}$ & $k$ \\
\hline River Brathay & United Kingdom & Froese and Pauly, 2016 & Female & 6.5 & 0.5 \\
River Brathay & United Kingdom & Froese and Pauly, 2016 & Male & 6.5 & 0.9 \\
Windermere & United Kingdom & Froese and Pauly, 2016 & Male & 7.2 & 0.7 \\
Windermere & United Kingdom & Froese and Pauly, 2016 & Female & 7.3 & 0.4 \\
Gorga creek & Italy & Present study & Unsexed & 1.32 & 1.56 \\
Cesano creek & Italy & Present study & Unsexed & 1.33 \\
\hline
\end{tabular}

Table 4. Parameters of the total-length-weight relationship for bullhead populations from Tiber river basin.

\begin{tabular}{lllrlll}
\hline Location & Country & References & $n$ & $T L$ range $(\mathrm{cm})$ & Length-weight relationship & $R^{2}$ \\
\hline Vallaccia creek & Italy & Froese and Pauly, 2016 & 42 & $3.4-12.0$ & $Y=0.007 \mathrm{x}^{3.304}$ & 0.98 \\
Bagni creek & Italy & Unpublished data & 146 & $3.5-12.8$ & $Y=0.008 \mathrm{x}^{3.230}$ & 0.95 \\
Topino river & Italy & Unpublished data & 135 & $3.0-14.2$ & $Y=0.010 \mathrm{x}^{3.162}$ & 0.96 \\
\hline
\end{tabular}

particular by the increase in the number of specimens belonging to the YOY age class $\left(0^{+}\right)$, as evidenced by the age-based demographic analysis. However, it seems clear that the beneficial effects due to the reduction of predation were compensated by the intraspecific competition related to the increase of the bullhead population density. In particular, as regards the competition among the age classes, the results of the body condition evaluation indicated that the younger specimens were the most adversely affected. Indeed, the inverse relationship between the abundance of bullhead and its body condition suggested the presence of intraspecific competition phenomena that would confirm this hypothesis. In any case, further analysis and testing will be needed to explore the presence of density-dependent population regulation for bullhead.

The information collected in the present study confirms the effectiveness of removal activities in the management of invasive alien species and in the protection of native fish biodiversity in Mediterranean areas. The obtained results are particularly important in consideration of the fact that the experiences of removal activities in Italian rivers are currently very limited. Our approach suggests that predator control could be effective in the short term, and the results confirmed the vulnerability of bullhead to the presence of brown trout as showing direct positive effects on the population dynamics related to the removal activities of the alien species.

Acknowledgements. This work was funded by Life+ TROTA Project (LIFE12 NAT/IT/0000940) for the recovery and conservation of Mediterranean trout (Salmo trutta complex) in the central Apennines (Italy), within the framework of the European Commission Life Projects. The authors wish to thank all of the people who joined in the field activities during the project. 


\section{References}

Anderson RO, Neumann, RM. 1996. Length, weight and associated structural indices. In Murphy BR, Willis DW, eds. Fisheries techniques. Bethesda: American Fisheries Society, pp. 447-483.

APAT, CNR, IRSA. 2003. Metodi analitici per le acque. Manuali e linee guida 29. [Analytical methods for water. Manuals and guidelines]. http://www.isprambiente.gov.it/it/pubblicazioni/man uali-e-linee-guida/metodi-analitici-per-le-acque.

Bagenal TB. 1978. Fish production in fresh waters. Oxford: Blackwell, $365 \mathrm{p}$.

Blackwell BG, Brown ML, Willis DW. 2000. Relative weight (Wr) status and current use in fisheries assessment and management. Rev Fish Sci 81: 1-44.

Brown ML, Austen, DJ. 1996. Data management and statistical techniques. In: Murphy BR, Willis DW, eds. Fisheries techniques. Bethesda: American Fisheries Society, pp. 17-62.

Carosi A, Ghetti L, Forconi A, Lorenzoni M. 2015. Fish community of the river Tiber basin (Umbria-Italy): temporal changes and possible threats to native biodiversity. Knowl Manag Aquat Ecosyst 416: 22 .

Carosi A, Ghetti L, Lorenzoni M. 2016. Status of Pseudorasbora parva in the Tiber river basin (Umbria, central Italy) 20 years after its introduction. Knowl Manag Aquat Ecosyst 417: 22.

Carosi A, Ghetti L, La Porta G, Lorenzoni M. 2017. Ecological effects of the European barbel Barbus barbus (L., 1758) (Cyprinidae) invasion on native barbel populations in the Tiber River basin (Italy). Eur Zool J 84: 420-435.

Charles S, Subtil F, Kielbassa J, Pont D. 2008. An individual-based model to describe a bullhead population dynamics including temperature variations. Ecol Modell 215: 377-392.

Cowx IG, Harvey GP. 2003. Monitoring the bullhead, Cottus gobio. Conserving Natura 2000 Rivers Monitoring Series No. 4. Peterborough: English Nature, 26 p.

Crowl TA, Townsend CR, Mcintosh AR. 1992. The impact of introduced brown and rainbow trout on native fish: the case of Australasia. Rev Fish Biol Fish 2: 217-241.

Didham RK, Tylianakis JM, Gemmell NJ, Rand TA, Ewers RM. 2007. Interactive effects of habitat modification and species invasion on native species decline. Trends Ecol Evol 22: 9.

Elliott JM. 2006. Periodic habitat loss alters the competitive coexistence between brown trout and bullheads in a small stream over 34 years. J Anim Ecol 75: 54-63.

Franchi E, Pompei L, Barbaresi R, et al. 2012. Distribution and abundance of European bullhead Cottus gobio in the watercourses of Pesaro-Urbino Province (Marche, central Italy). Ital J Freshw Ichthyol 2: 48-56.

Freyhof J, Kottelat M, Nolte A. 2005. Taxonomic diversity of European Cottus with description of eight new species (Teleostei: Cottidae). Ichthyol Explor Freshw 16: 107-172.

Froese F, Pauly D. Editors. 2016. FishBase. World Wide Web electronic publication. http://www.fishbase.org, version (01/2016).

Gandolfi G, Zerunian S, Torricelli P, Marconato A. 1991. I pesci delle acque interne italiane [The fish of Italian inland waters]. Rome: Istituto Poligrafico e Zecca dello Stato, 606 p.

Giannetto D, Carosi A, Franchi E, et al. 2012. Assessing the impact of non-native freshwater fishes on native species using relative weight. Knowl Manag Aquat Ecosyst 404: 03.

Gosselin MP, Petts GE, Maddock IP. 2010. Mesohabitat use by bullhead (Cottus gobio). Hydrobiologia 652: 299-310.

Hermoso V, Clavero M. 2011. Threatening processes and conservation management of endemic freshwater fish in the Mediterranean basin: a review. Mar Freshw Res 62: 244-254.
Holmen J, Olsen EM, Vøllestad LA. 2003. Interspecific competition between stream-dwelling brown trout and Alpine bullhead. J Fish Biol 62: 1312-1325.

Irons KS, Sass GG, Mcclelland MA, Stafford JD. 2007. Reduced condition factor of two native fish species coincident with invasion of non-native Asian carps in the Illinois River, U.S.A. Is this evidence for competition and reduced fitness? J Fish Biol 71: 258 273.

Jermacz Ł, Kobak J, Dzierzyńska A, Kakareko T. 2015. The effect of flow on the competition between the alien racer goby and native European bullhead. Ecol Freshw Fish 24: 467-477.

Knaepkens G, Bruyndoncx L, Coeck J, Eens M. 2004. Spawning habitat enhancement in the European bullhead (Cottus gobio), an endangered freshwater fish in degraded lowland rivers. Biodivers Conserv 13: 2443-2452.

Le Cren ED. 1951. The length relationship and seasonal cycle in gonad weight and condition in the perch (Perca fluviatilis). J Anim Ecol 20: 210-218.

Legalle M, Santoul F, Figuerola J, Mastrorillo S, Céréghino R. 2005. Factors influencing the spatial distribution patterns of the bullhead (Cottus gobio L., Teleostei Cottidae): a multi-scale study. Biodivers Conserv 14: 1319-1334.

Lorenzoni M, Esposito L. 2011. La Carta Ittica delle Marche. Regione Marche, Ancona: Assessorato Caccia e Pesca.

Lorenzoni M, Mearelli M, Ghetti L. 2006. Native and exotic fish species in the Tiber river watershed (Umbria - Italy) and their relationship to the longitudinal gradient. Bulletin français de la pêche et de la pisciculture 382: 19-44.

Lorenzoni M, Ghetti L, Carosi A, Dolciami R. 2010. La fauna ittica e i corsi d'acqua dell'Umbria. Sintesi delle Carte Ittiche regionali dal 1986 al 2009. Perugia: Petruzzi Editore, 288 p.

Louhi P, Mäki-Petäys A, Huusko A, Muotka T. 2014. Resource use by juvenile brown trout and Alpine bullhead: influence of interspecific versus intraspecific competition. Ecol Freshw Fish 23: 234-243.

Mann RHK. 1971. The Populations, Growth and Production of Fish in Four Small Streams in Southern England. J Anim Ecol 40: 155-190.

Marconato A. 1986. Distribuzione dell'ittiofauna e gestione della pesca. Quaderni ETP 14: 139-149.

Marr MS, Olden JD, Leprieur F, et al. 2013. A global assessment of freshwater fish introductions in mediterranean-climate regions. Hydrobiologia 719: 317-329.

Mills C, Mann RHK. 1983. The bullhead Cottus gobio, a versatile and successful fish. Rep Freshw Biol Assoc 51: 76-88.

Mooney HA, Cleland EE. 2001. The evolutionary impact of invasive species. PNAS, 98: 5446-5451. DOI: 10.1073ypnas.091093398.

Moran PAP. 1951. A mathematical theory of animal trapping. Biometrika 38: 307-311.

Muus BJ, Dahlström P. 1968. Süßwasserfische. München: BLV Verlagsgesellschaft, $242 \mathrm{p}$.

Pauly D, Munro JL. 1984. Once more on comparison of growth in fish and invertebrates, ICLARM. Fishbyte 1: 21-22.

Pedicillo G, Carosi A, Ghetti L, Lorenzoni M. 2010. Population size structure indices and growth standards for Salmo (trutta) trutta Linnaeus, 1758 in Central Italy. Knowl Manag Aquat Ecosyst 399: 02.

Penczak T. 1999. Impact of introduced brown trout on native fish communities in the Pilica River catchment (Poland). Environ Biol Fishes 54: 237-252.

Ribeiro F, Leunda PM. 2012. Non-native fish impacts on Mediterranean freshwater ecosystems: current knowledge and research needs. Fish Manage Ecol 19: 142-156.

Ricker WE. 1975. Computation and interpretation of biological statistics of fish populations. J Fish Res Board Can 191: 382 
M. Lorenzoni et al.: Knowl. Manag. Aquat. Ecosyst. 2018, 419, 22

Seber GAF, Le Cren ED. 1967. Estimating population parameters from catches larges relative to the population. J Anim Ecol 36: 631-643.

Simon KS, Townsend CR. 2003. Impacts of freshwater invaders at different levels of ecological organization, with emphasis on salmonids and ecosystems consequences. Freshw Biol 48: 982-994.

Smith KG, Darwall WRT. 2006. The Status and Distribution of Freshwater Fish Endemic to the Mediterranean Basin. Gland and Cambridge, $34 \mathrm{p}$.

Sokal RR, Rohlf FL. 1987. Introduction to biostatistics. New York: Freeman, $887 \mathrm{p}$.

Tomlinson ML, Perrow MR. 2003. Ecology of the bullhead. Conserving Natura 2000 Rivers Ecology Series No. 4. Peterborough: English Nature, $16 \mathrm{p}$.

Ter Braak CJF. 1986. Canonical correspondence analysis: a new eigenvector technique for multivariate direct gradient analysis. Ecology 67: 1167-1179.
Townsend CR. 1996. Invasion biology and ecological impacts of brown trout Salmo trutta in New Zealand. Biol Conserv 78: 13-22.

Utzinger J. Roth C, Peter A. 1998. Effects of environmental parameters on the distribution of bullhead Cottus gobio with particular consideration of the effects of obstructions. J Appl Ecol 35: 882-892.

Van Liefferinge C, Seeuws P, Meire P, Verheyen RF. 2005. Microhabitat use and preferences of the endangered Cottus gobio in the River Voer, Belgium. J Fish Biol 67: 897-909.

von Bertalanffy L. 1938. A quantitative theory of organic growth. Hum Biol 10: 181-243.

Zerunian S. 2002. Iconografia dei pesci delle acque interne d'Italia [Iconography of Italian inland water fishes]. Modena: Tipolitografia $\mathrm{FG}, 259 \mathrm{p}$.

Zippin C. 1956. An evaluation of the removal method of estimating animal populations. Biometrics 12: 163-189.

Cite this article as: Lorenzoni M, Carosi A, Giovannotti M, Porta GL, Splendiani A, Barucchi VC. 2018. Population status of the native Cottus gobio after removal of the alien Salmo trutta: a case-study in two Mediterranean streams (Italy). Knowl. Manag. Aquat. Ecosyst., 419, 22. 
M. Lorenzoni et al.: Knowl. Manag. Aquat. Ecosyst. 2018, 419, 22

\section{Appendices}

\section{Appendix}

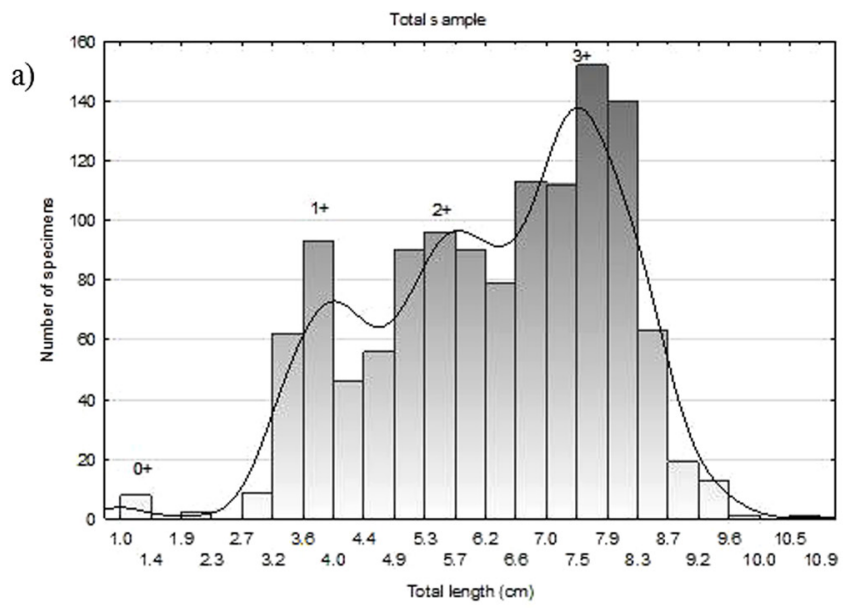

b)
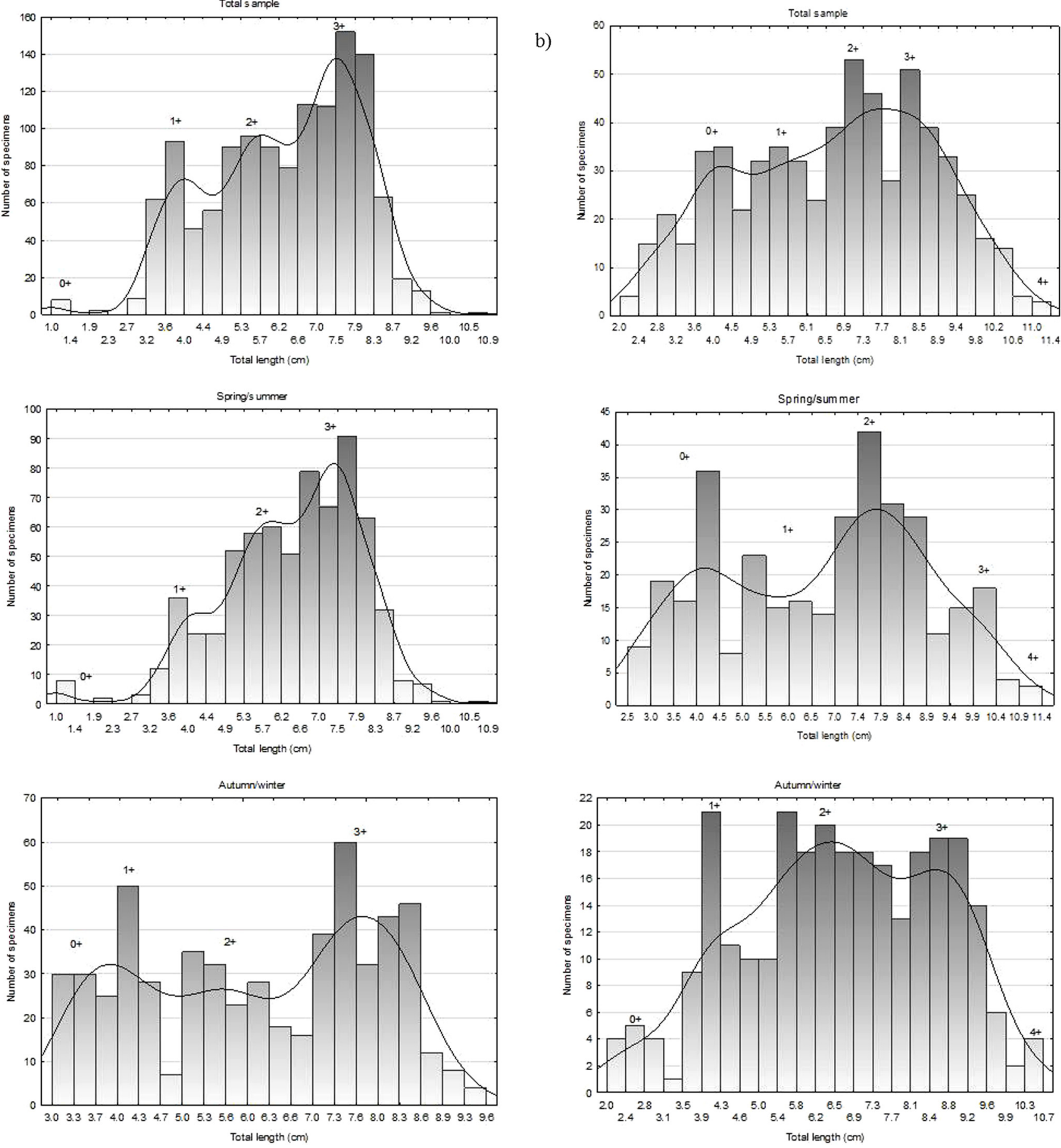